\title{
Social life cycle assessment of biomethane production and distribution in Latvia
}

\author{
Katrina Karklina, Dzintra Slisane, Francesco Romagnoli, Dagnija Blumberga \\ Riga Technical University, Institute of Energy Systems and Environment. \\ Address: Azenes street 12/1, Riga, LV 1048, Latvia
}

\begin{abstract}
A social life cycle assessment is proposed for the evaluation of the social potential impact in regard to the production and use of biomethane derived from biomass (algae and manure) in Latvia. The Multi-Criteria Analysis (MCA) is used to evaluate the social performances, which have been selected based on literature, statistics and legislation data. Seven alternatives are evaluated by experts and the best alternative is figured out.
\end{abstract}

Keywords: biomethane, multi-criteria analysis, social impacts, social life cycle assessment.

\section{INTRODUCTION}

Biomethane production from algae and manure raw materials and its use in motor transport or energy production is an alternative to the use of fossil fuel. Life Cycle Assessment has shown in several studies the beneficial effect of the biomethane production pathway from an environmental point of view [1]; toward an overall sustainability perspective the social aspects represents a key issue and the Social Life Cycle Assessment (hereafter - S-LCA) a proper methodology for a wider analysis of the system. SLCA is a technique that aims to assess the potential impact of a specific product of service toward an holistic approach, basically a cradle-to-grave approach that considers the extraction of raw materials till turning into waste [2]. Traditionally life cycle perspective is conducted for the evaluation of environmental impacts, but nowadays the attention is addressed to the social dimension, which sometimes is more difficult for a quantitative final evaluation.

Several studies and methodologies assessing the social performances have been already conducted. In 2009 the United Nations Environmental Programme (UNEP) proposed specific guidelines and methodological sheets for conducting the S-LCA process [2], [3]. Macombe et al. [4] pointed out an important research aiming to improve the methodological and empirical basis of the S-LCA at various levels of decision-making.

Dzene et al. [5] proposed a study based on a multicriteria analysis for the evaluation of biogas use under different hypothetical scenarios for the Latvian conditions. However, only one potential social criterion was proposed in the study and thus included within the comparison, mostly due to the difficulty to collect quantitative information in regard to the social aspects.

The aim of this paper is to evaluate the possibilities of biomethane use in different applications in Latvia, highlighting the application in the area of transport.

\section{MATERIALS AND METHODS}

\section{A. Goal and scope definition}

According to [2], the first step for the evaluation of social impact under S-LCA perspective is to highlight and identify stakeholder groups, that can be identify in terms of:

- Local community,

- Society,

- Workers,

- Consumers,

- Value chain actors.

Specific indicators within the inventory should be associated to each stakeholder group, which are assessed, taking into account information about product, or process under analysis as well as background information, which describes the situation in the state. The result of the S-LCA is strongly dependent on the geography of manufacturing and distribution of the analyzed product or system, and is also taking into consideration the non-homogeneity of welfare of nowadays world.

Looking toward the opportunity to use novel feedstock for biomethane production, marine macro algae represent an important perspective in this direction. This aspect is topical for Latvia if we consider the high level of eutrophication of the Baltic Sea that thus tent to increase the amount of growing algae biomass. Due to the difficulties to harvest marine macro algae during the winter time the co- 
digestion with manure would represent a viable opportunity.

At the moment, there is no algae use for biomethane production implemented any biogas plant in Latvia, for this reason the proposed analysis is provided based on the information collected from the literature sources, legislative acts, statistical reports and reports about other similar experiences contextualized the situation of Latvia.

To evaluate the biomethane implementation from the social welfare point of view, the process is divided into the principle unit processes (or stages) that may have an impact on different social groups:

- Supply of a raw material (algae, manure),

- Raw material treatment into biomethane,

- Biomethane storage and distribution,

- Efficient usage of a digestate as a by-product of the process.

The considered stages also define the system boundary, in which the assessment is carried out. The inventory analysis is structured, being based on the distribution of processes and stakeholder groups.

According to [4], the role of the functional unit should be clarified from a LCA perspective and harmonized with the S-LCA scheme, but not always this is possible.

In fact with reference to the UNEP/SETAC (2009) methodology the S-LCA should embraced the assessment of the potential social impact through the correct selection and the analysis of social indicators. This must be in connection to the typical holistic approach of the LCA methods that involves the definition of the functional unit and system boundaries, and the final impact assessment.

The selection of the indicators is thus the crucial and key issues of the S-LCA, most of the time because are referenced to qualitative and subjective evaluations, but also because site specific information often lacking of specific information or are related to time spending analysis (such as questionnaire, face-toface meeting with experts and/or local companies, etc..).

The "non-physical" aspects related to the information to be collected is one bottle-neck of the SLCA method mostly if we are considering that then the social aspects must be related to a functional unit that foresees allocation and aggregation of multiinput and output unit processes toward the whole life cycle.

From a preliminary literature review it has been noticed that not many focused studies have been performed on the application of S-LCA methodology to the biomethane context (and thus connected to the fertilizer as well), but several theoretical argument have been discuss within the scientific arena [15].

Nevertheless if one is looking toward the use of the results as support tool for final decision for specific decisional scenarios the solely S-LCA should be not enough to match this question.

\section{B. Inventory analysis: background information}

According to [6], in the 4th quarter of year 2014 the level of unemployed inhabitants in Latvia reached the percentage of $33.5 \%$, which means a third of the social group within the age range of 15-74 years. The net migration rate has been negative since 1991, and in 2013 it was 14262 [7].

Biomethane production and infrastructure system establishment in practise may have an important impact respect the social situation mostly in connection with two issues:

- $\quad$ standard of living changes,

- $\quad$ social cohesion and stability [8].

Social cohesion is a characterization of a society, the main characteristics are the strengthening of the social relations, feeling of a common identity, trust among societal members, shared values, etc. [9].

Standard of living from an economic point of view characterizes a consumption level of a household or its income rate [8]. It is important to note that this factor has also a long-term impact such as the possibility to get education and healthcare [8]; education is one of the uppermost factors for further funding of social employment and healthcare directly affects inhabitants' capacity for work and lifespan.

\section{Inventory analysis: supply of raw materials, biomethane production, distribution and use of digestate}

Stakeholders for all the process stages are local community, society and workers; biomethane storage and production also involve important effects on the value chain actors and thus can be selected as indicators for the multi-criteria analysis. Specifically the selected indicators are employment, standard of living, rational use of resources, environmental protection and security of energy supply. Moreover growth of economy, lack of competition with food crops for arable land, working conditions, fair competition etc would represent important and critical indicator to be further investigated.

For this specific case study it is suggested that manure would be delivered from the local rural areas, while for the collection of algae as feedstock two ways are proposed:

- Industrial cultivation,

- Collection of natural growing algae, i.e. the Baltic Sea.

One can consider the algae growing as a link and opportunity to raise the economic situation in a specific region thus increasing the interest of local community. The use of manure is a possibility for farmers and agricultural workers to get an additional income. According to the statistical data [10], 74K of inhabitants were employed in agriculture, forestry and fisheries in 2012. Total number of inhabitants in 2012 was 2207708 [11], which means that about 3\% of inhabitants were engaged in these areas. 
One of the advantages of algae use is the fact that there is no competition with food crops for arable lands $[12,13]$. The same may be referred to manure, because it is a by-product of livestock farming not the primary end-product. Because of this, as well as of the reason that biofuel is not produced from such feedstock as corn or sugarcane, production of biomethane from algae and manure do not impact the food prices, as it is in the case of the first generation biofuels [12]. Food prices are one of the factors, which directly impact the social welfare.

As for biomethane production, plant installation can provide work places for the local community, wherewith also income and motivation not to cross the state border in the reason of employment. Amount and specificity of work places depend on the plant's production volume and level of automatization. The presence of work places is also a motive for rising generations to matriculate to specialized educational establishments and to acquire practically applicable knowledge and skills.

For storage and distribution of biomethane, a network of fuel filling stations is needed, in which biomethane would be storaged in a compressed form. This means that stations should be raised and maintained, which in both cases provides employment and welfare in the state.

Use of digestate is planned in 3 (three) types: In form of pellets for energy production, As a fertilizer in agriculture, As a building material.

In this case raw materials for other economic sectors are provided as a by-product of biomethane extraction; this fact raises the efficiency of use of the raw material and is connected with the welfare of the local community.

Use of digestate as an organic fertilizer is preferable for the local community, because it promotes the decrease of the concentration of nitrates in groundwater and drinking water; digestate is also preferable for the whole society, because consumers of crops, cultivated with the digestate as a fertilizer, may be located in distance from the agricultural territories.

Use of digestate in the form of pellets as a biofuel reduces the increase of carbon dioxide $\left(\mathrm{CO}_{2}\right)$ in the atmosphere and thereby prevents climate change caused by the global warming, and in such way positively influences the society's health.

One of examples for digestate use as a building material is the use of its dry fibers as a filling in plywood and similar materials. It may be considered as an economy of resources, which might be assessed positively from the point of view of local community and society.

\section{Multi-criteria analysis}

Macombe et al. [4] ascertained that multi-criteria decision analysis techniques can provide a methodological framework for the S-LCA.

The Technique for Order of Preference by Similarity to Ideal Solution (TOPSIS) is applied for the assessment of social performances, by analogy on [5], [14].

Basic element of TOPSIS analysis is data matrix:

$$
\begin{aligned}
& \begin{array}{llllll}
x_{1} & x_{2} & \cdots & x_{j} & \cdots & x_{n}
\end{array} \\
& A_{1}\left[\begin{array}{llllll}
x_{11}^{k} & x_{12}^{k} & \cdots & x_{1 j}^{k} & \cdots & x_{1 n}^{k}
\end{array}\right] \\
& \begin{array}{l|llllll}
A_{2} & x_{21}^{k} & x_{22}^{k} & \cdots & x_{2 j}^{k} & \cdots & x_{2 n}^{k}
\end{array} \\
& \begin{array}{llllllll}
\vdots & \vdots & \vdots & \ldots & \vdots & \ldots & \vdots
\end{array} \\
& \begin{array}{c|cccccc}
A_{i} & x_{i 1}^{k} & x_{i 2}^{k} & \cdots & x_{i j}^{k} & \cdots & x_{i m}^{k}
\end{array} \\
& \vdots \begin{array}{lllllll} 
& \vdots & \vdots & \ldots & \vdots & \ldots & \vdots
\end{array} \\
& A_{n}\left[\begin{array}{llllll}
x_{n 1}^{k} & x_{n 2}^{k} & \cdots & x_{n j}^{k} & \cdots & x_{n m}^{k}
\end{array}\right.
\end{aligned}
$$

Where $\left\{\mathrm{A}_{1}, \mathrm{~A}_{2}, \ldots, \mathrm{A}_{\mathrm{i}}, . ., \mathrm{A}_{\mathrm{m}}\right\}$ represent alternatives.

Seven scenarios with five criteria are evaluated by experts, where the scenarios $\left.\left(\mathrm{A}_{1} \ldots \mathrm{A}_{7}\right)\right)$ are:

- Biogas to heat (A1),

- $\quad$ Biogas to heat and power (CHP) (A2),

- Biomethane with grid injection to heat (A3),

- Biomethane with grid injection to CHP (A4),

- Biomethane with grid injection to transport (A5),

- $\quad$ Biomethane directly to transport (A6),

- Natural gas $\left(\mathrm{A}_{7}\right)$,

And the criteria $\left(\mathrm{x}_{1} \ldots \mathrm{x}_{5}\right)$ or indicators, are social performances:

- Employment,

- Standard of living,

- Environmental protection,

- Rational use of resources,

- $\quad$ Security of energy supply.

The specific weights for all the criteria are regarded as equal. To make data comparable, the normalization of the values is carried out as in (2) and tabulated in a matrix.

$$
b_{i}=\frac{x_{i}}{\sum_{i=1}^{7} x_{i}}
$$

Normalized and weighted matrix is calculated:

$$
v_{i j}=b_{i j} \cdot w_{i}
$$

The determination of positive and negative ideal solution is done:

$$
A^{+}=\max _{i} w_{j} b_{i j}
$$




$$
A^{-}=\min _{i} w_{j} b_{i j}
$$

Separation from Positive Ideal Solution $\left(\mathrm{S}^{+}\right)$and Negative Ideal Solution $\left(\mathrm{S}^{-}\right)$is calculated:

$$
\begin{aligned}
& S^{+}=\sqrt{\sum_{j=1}^{n}\left(v_{i j}-v_{i j}^{+}\right)^{2}} \\
& S^{-}=\sqrt{\sum_{j=1}^{n}\left(v_{i j}-v_{i j}^{-}\right)^{2}}
\end{aligned}
$$

Relative closeness to the Ideal Solution:

$$
C_{i}^{*}=\frac{s_{i}^{+}}{\left(s_{i}^{+}-s_{i}^{-}\right)}
$$

\section{RESULTS AND DISCUSSION}

The normalised and weighted decision making matrix is given in Table 1 , where $A_{1}-A_{7}$ are the scenarios, and $\mathrm{A}^{+}\left(\mathrm{v}_{\mathrm{j}}^{+}\right)$and $\mathrm{A}^{-}\left(\mathrm{v}_{\mathrm{j}}{ }^{-}\right)$are the maximum

\begin{tabular}{|c|c|c|c|c|c|c|c|c|}
\hline & Employment & $\begin{array}{l}\text { Standard } \\
\text { of living }\end{array}$ & $\begin{array}{l}\text { Environmental } \\
\text { protection }\end{array}$ & $\begin{array}{l}\text { Rational use of } \\
\text { resources }\end{array}$ & $\begin{array}{l}\text { Security of } \\
\text { energy supply }\end{array}$ & $\mathrm{S}^{+}$ & $\mathrm{S}^{-}$ & Rating \\
\hline $\begin{array}{l}\text { Criterion } \\
\text { Weight }\end{array}$ & 0.2 & 0.2 & 0.2 & 0.2 & 0.2 & $\mathrm{n} / \mathrm{a}$ & $\mathrm{n} / \mathrm{a}$ & $\mathrm{n} / \mathrm{a}$ \\
\hline $\mathrm{A}_{1}$ & 0.0697 & 0.0704 & 0.0742 & 0.0583 & 0.0786 & 0.0488 & 0.0778 & 0.6143 \\
\hline $\mathrm{A}_{2}$ & 0.0766 & 0.0861 & 0.0865 & 0.0907 & 0.0846 & 0.0154 & 0.1071 & 0.8745 \\
\hline $\mathrm{A}_{3}$ & 0.0766 & 0.0704 & 0.0680 & 0.0454 & 0.0725 & 0.0602 & 0.0721 & 0.5452 \\
\hline $\mathrm{A}_{4}$ & 0.0836 & 0.0783 & 0.0865 & 0.0843 & 0.0786 & 0.0177 & 0.1021 & 0.8520 \\
\hline$\overline{A_{5}}$ & 0.0836 & 0.0783 & 0.0865 & 0.0972 & 0.0846 & 0.0105 & 0.1113 & 0.9140 \\
\hline $\mathrm{A}_{6}$ & 0.0906 & 0.0861 & 0.0804 & 0.0907 & 0.0846 & 0.0090 & 0.1104 & 0.9249 \\
\hline $\mathrm{A}_{7}$ & 0.0348 & 0.0548 & 0.0309 & 0.0389 & 0.0302 & 0.1164 & 0.0000 & 0.0000 \\
\hline $\mathrm{A}^{+}\left(\mathrm{v}_{\mathrm{j}}^{+}\right)$ & 0.0906 & 0.0861 & 0.0865 & 0.0972 & 0.0846 & 0.0000 & 0.1164 & $\mathrm{n} / \mathrm{a}$ \\
\hline$A^{-}\left(v_{j}^{-}\right)$ & 0.0348 & 0.0548 & 0.0309 & 0.0389 & 0.0302 & 0.1164 & 0.0000 & $\mathrm{n} / \mathrm{a}$ \\
\hline
\end{tabular}
and minimum values, respectively.

TABLE I

NORMALISED AND WEIGHTED DECISION MAKING MATRIX

Rating, or relative closeness to the Ideal Solution, is shown in Fig.1:

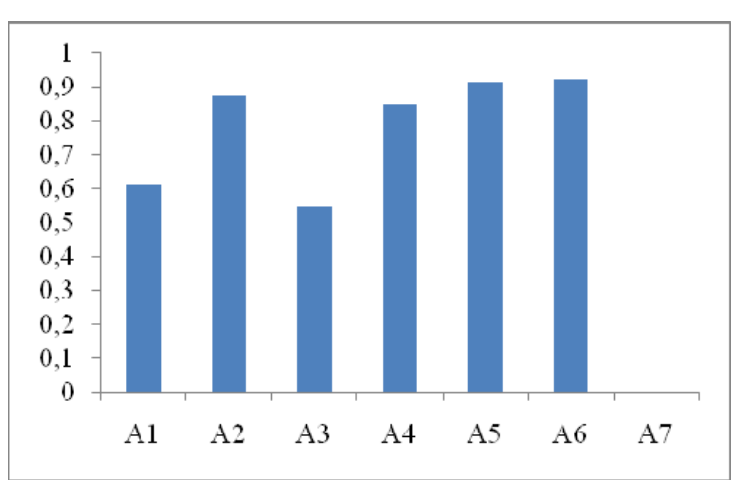

Fig.1. Rating (relative closeness to the Ideal Solution) for the evaluated scenarios

According to Fig.1, $\mathrm{A}_{6}$ (biomethane directly to transport) has the closest to the Ideal Solution value, which is 0.9249 . $\mathrm{A}_{5}$, biomethane with grid injection to transport, has value 0.9140 and is the second of the best alternatives.

Comparing to other alternatives, natural gas is evaluated as unacceptable variant, and its rating is 0.0000

$\mathrm{A}_{6}$ scenario has maximum values for such indicators as employment, standard of living and security of energy supply. For the environmental protection maximal value has $\mathrm{A}_{4}$ scenario (biomethane with grid injection to combined heat and power), and for rational use of resources $-\mathrm{A}_{5}$ (biomethane with grid injection to transport).

\section{CONCLUSIONS}

Main social performances for the infrastructure of biomethane production, distribution and use in Latvia are analysed and multi-criteria analysis for corresponding alternatives is carried out. Social life cycle assessment is done according to the international guidelines of UNEP [2].

Biomethane use is evaluated as applicable for Latvian conditions, being based on the social considerations. Employment, standard of living and rational use of local resources, as well as environmental protection and security of energy supply are the main social performances, whose positive effect on the society is approved.

The result of multi-criteria analysis shows that biomethane injection directly to transport is the most appropriate alternative from the offered, and natural gas use is undesirable.

\section{$\mathrm{V}$ ACKNOWLEDGEMENT}

This work has been supported by the European Social Fund project "Involvement of Human Resources for Development of Integrated Renewable Energy Resources Energy Production System" (project No. 2013/0014/1DP/1.1.1.2.0/13/APIA/ VIAA/026). 


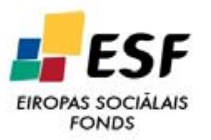

FONDS

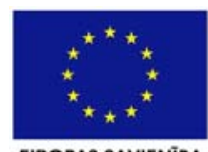

EIROPAS SAVIENİBA

\section{IEGULDĪJUMS TAVĀ NĀKOTNĒ}

\section{REFERENCES}

[1] B. Morero, E. Groppelli, E. A. Campanella, "Life cycle assessment of biomethane use in Argentina", Bioresource Technol, vol. 182, pp. 208-216, Jan 2015.

[2] C. Benoit, B. Mazijn, Guidelines for Social Life Cycle Assessment of Products. United Nations Environment Programme, 2009

[3] C. Benoit Norris, M. Traverso, S. Valdivia, G. VickeryNiederman, et al. The Methodological Sheets for Subcategories in Social Life Cycle Assessment (S-LCA). Pre-publication version. United Nations Environment Programme, SETAC, 2013.

[4] C. Macombe, P. Leskinen, P. Feschet, R. Antikainen, "Social life cycle assessment of biodiesel production at three levels: a literature review and development needs", J Clean Prod, vol. 52, pp. 205-216, Mar 2013.

[5] I. Dzene, F. Romagnoli, G. Seile, D. Blumberga, "Comparison of different biogas use pathways for Latvia: biogas use in CHP vs. biogas upgrading", in press.

[6] Central Statistical Bureau of Latvia, "NB01, Population by labour status, sex and quarter", [Online]. Available: http://www.csb.gov.lv/ [Accessed: Feb. 26, 2015].

[7] Central Statistical Bureau of Latvia, "IBG01.Long-term migration", [Online]. Available: http://www.csb.gov.lv/ [Accessed: Feb. 26, 2015].
[8] J. Domac, K. Richards, S. Risovic, "Socio-economic drivers in implementing bioenergy projects", Biomass Bioenerg, vol. 28, pp.97-106, Oct 2004.

[9] R. Berger-Schmitt, Social cohesion as an aspect of the quality of societies: concept and measurement, EuReporting working paper No.14, Mannheim: EuReporting, 2000.

[10] Central Statistical Bureau of Latvia, "Agriculture in Latvia. Collection of statistical data", 2013, [Online]. Available: http://www.csb.gov.lv/sites/default/files/nr_30_latvijas_lau ksaimnieciba_2013_13_00_lv_en.pdf [Accessed: Feb. 27, 2015].

[11] Pilsonības un migrācijas lietu pārvalde, „Latvijas iedīvotāju skaits pašvaldībās", [Online]. Available: http://www.pmlp.gov.lv/lv/assets/documents/statistika/IRD _01_07_2012/ISPV_Pasvaldibas_iedzivotaju_skaits.pdf [Accessed:Feb. 17, 2015] [in Latvian].

[12] M. E. Montingelli, S. Tedesco, A. G. Olabi, "Biogas production from algal biomass: A review", Renew Sust Energ Rev, vol. 43, pp. 961-972, Dec. 2014.

[13] A. Singh, S. I. Olsen, "A critical review of biochemical conversion, sustainability and life cycle assessment of algal biofuels", Appl Energ, vol. 88, pp. 3548-3555, Jan 2011.

[14] D. Lauka, "Low carbon energy waste. Physical properties", M.S. thesis, Riga Technical University, Riga, Latvia, 2014.

[15] J. Martínez-Blanco, A. Lehmann, P. Muñoz, A. Antón, M.Traverso, J. Rieradevall, and M. Finkbeiner. Application challenges for the social Life Cycle Assessment of fertilizers within life cycle sustainability assessment. J Clean Prod, vol. 69, pp. 34-48, 2014. 